\title{
СУИЦИДАЛЬНОЕ ПОВЕДЕНИЕ КАК ФАКТОР РИСКА СОЦИАЯЬНОЙ ОПАСНОСТИ ПАЦИЕНТОВ С РАССТРОЙСТВАМИ ШИЗОФРЕНИЧЕСКОГО CחEKTPA
}

\author{
И.Н. Винникова, А.С. Дмитриев, Б.С. Положий, О.И. Печенкина, Д.Ю. Ермолаева \\ ФГБУ «Национальный медицинский исследовательский центр психиатрии и наркологии имени \\ В.П.Сербского" Минздрава России, г. Москва, Россия

\section{SUICIDAL BEHAVIOR AS A RISK FACTOR OF SOCIAL DANGER IN PATIENTS WITH SCHIZOPHRENIC SPECTRUM DISORDERS}

\author{
I.N. Vinnikova, A.S. Dmitriev, B.S. Polozhy, \\ O.I. Pechenkina, D. Yu. Ermolaeva
}

V. Serbsky National Medical Research Centre for Psychiatry and Narcology, Moscow, Russia

Контактная информация:

Винникова Ирина Николаевна - доктор медицинских наук (SPIN-код: 5464-2215; Researcher ID: Y-73612018; ORCID iD: 0000-0002-7153-9834). Место работы и должность: руководитель отделения эндогенных психозов ФГБУ “Национальный медицинский исследовательский центр психиатрии и наркологии им. В.П. Сербского» Минздрава России. Адрес: Россия, 119992, г. Москва, Кропоткинский пер., 23. Темефон: +7 (495) 637-70-13, эмектронный адрес: irvina1@yandex.ru

Дмитриев Андрей Сергеевич - доктор медицинских наук, профессор (SPIN-код: 7427-7940; Researcher ID: AAE-6174-2019; ORCID iD: 0000-0003-0310-3606). Место работы и должность: руководитель отделения по разработке принципов мечения в судебной психиатрии ФГБУ "Национальный медицинский исследовательский центр психиатрии и наркологии им. В.П. Сербского" Минздрава России. Адрес: Россия, 119992, г. Москва, Кропоткинский пер., 23. Темефон: +7 (495) 637-25-42, эмектронный адрес: sabanrus@yandex.ru

Положий Борис Сергеевич - доктор медицинских наук, профессор, Заслуженный деятель науки РФ (SPINкод: 1734-3563; AuthorID: 959343; Researcher ID:X-9588-2018; ORCID iD: 0000-0001-5887-8885). Место работы и должность: руководитель Отдемения клинической и профилактической суицидологии Московского НИИ психиатрии - филиала ФГБУ “Национальный медицинский исследовательский центр психиатрии и наркологии им. В.П. Сербского" Минздрава России. Адрес: Россия, 119992, г. Москва, Кропоткинский пер., 23. Темефон: +7 (906) $776-$ 24-68; эмектронный адрес: pbs.moscow@gmail.com

Печенкина Ольга Игоревна - кандидат медицинских наук (SPIN-код: 4547-1240; Researcher ID: AAE-96042019; ORCID iD: 0000-0003-1803-9838). Место работы и должность: старший научный сотрудник отдемения эндогенных психозов ФГБУ «Национальный медицинский исследовательский центр психиатрии и наркологии им. В.П. Сербского" Минздрава России. Адрес: Россия, 119992, г. Москва, Кропоткинский пер., 23. Темефон: +7 (495) 63770-13, эмектронный адрес: pechenkina.o@serbsky.ru

Ермолаева Дарья Юрьевна (SPIN-код: 8276-3153; Researcher ID: AAB-3788-3153; ORCID iD: 0000-00019045-8995). Место работы и должность: аспирант отделения эндогенных психозов ФГБУ «Национальный медицинский исследовательский центр психиатрии и наркологии им. В.П. Сербского" Минздрава России. Адрес: Россия, 119992, г. Москва, Кропоткинский пер., 23. Темефон: +7 (495) 637-70-13, эмектронный адрес: 2204198466@mail.ru

Contact Information:

Vinnikova Irina Nikolaevna - Doctor of Medical Sciences (SPIN-code: 5464-2215; Researcher ID: Y-7361-2018; ORCID iD: 0000-0002-7153-9834). Place of work and position: Head of the Department of Endogenous Psychoses, Ministry of Health of Russia FSBI National Medical Research Center for Psychiatry and Narcology after V.P. Serbsky. Address: Russia, 119992, Moscow, Kropotkinskiy per. 23. Phone: +7 (495) 637-70-13, email: irvina1@yandex.ru

Dmitriev Andrei Sergeevich - Doctor of Medical Sciences, Professor (SPIN-code: 7427-7940; Researcher ID: AAE6174-2019; ORCID iD: 0000-0003-0310-3606). Place of work and position: Head of the Department for the Development of Treatment Principles in Forensic Psychiatry, Ministry of Health of Russia FSBI National Medical Research Center for Psychiatry and Narcology after V.P. Serbsky. Address: Russia, 119992, Moscow, Kropotkinskiy per. 23. Phone: +7 (495) 637-25-42, email: sabanrus@yandex.ru

Polozhy Boris Sergeevich - Doctor of Medical Sciences, Professor, Honored Scientist of the Russian Federation (SPIN code: 1734-3563; AuthorID: 959343; Researcher ID: X-9588-2018; ORCID iD: 0000-0001-5887-8885). Place of work and position: Head of the Clinical and Preventive Suicidology Department of the Moscow Research Institute of Psychiatry, a branch of Ministry of Health of Russia FSBI National Medical Research Center for Psychiatry and Narcology after V.P. Serbsky. Address: Russia, 119992, Moscow, Kropotkinskiy per. 23. Phone: +7 (906) 776-24-68; email address: pbs.moscow@gmail.com

Pechenkina Olga Igorevna - PhD in medical sciences (SPIN code: 4547-1240; Researcher ID: AAE-9604-2019; ORCID iD: 0000-0003-1803-9838). Place of work and position: Senior Researcher, Department of Endogenous Psychoses, Ministry of Health of Russia FSBI National Medical Research Center for Psychiatry and Narcology after V.P. Serbsky. Address: Russia, 119992, Moscow, Kropotkinskiy per. 23. Phone: +7 (495) 637-70-13, email: pechenkina.o@serbsky.ru 
Ermolaeva Daria Yuryevna (SPIN-code: 8276-3153; Researcher ID: AAB-3788-3153; ORCID iD: 0000-0001-90458995). Place of work and position: post-graduate student of the Department of Endogenous Psychoses of Ministry of Health of Russia FSBI National Medical Research Center for Psychiatry and Narcology named after V.P. Serbsky. Address: Russia, 119992, Moscow, Kropotkinskiy per. 23. Phone: +7 (495) 637-70-13, email: 2204198466@mail.ru

Целью настоящего исследования являлось определение связи между суицидальным поведением в анамнезе и особенностями криминальной агрессии у больных шизофренией. Материал и методы: Обследовано 276 больных шизофренией и шизотипическим расстройством, совершивших общественно опасные деяния и проходивших судебно-психиатрическую экспертизу в ФГБУ «НМИЦ ПН им. В.П. Сербского» Минздрава России. У всех обследованных в анамнезе отмечались суицидальные попытки. В исследовании использовались клинико-психопатологический и психометрический методы. Оценка клинических симптомов шизофрении проводилась с помощью Шкалы позитивных и негативных синдромов (PANSS). В зависимости от тяжести совершённого противоправного деяния обследуемые были разделены на две группы: I - с проявлениями гетероагрессии и II - без таковой. Математическую обработку данных проводили с помощью программ SPSSStatistics и Statistica 12. Результаты: Установлено, что характеристики суицидального поведения у пациентов I группы достоверно отличались более высокими показателями по совершению первого акта аутоагрессии в возрастном периоде 26-30 лет, на начальных этапах заболевания, преобладанию истинных суицидальных попыток, их ассоциированности с употреблением алкогольных напитков, меньшей продолжительности интервала между суицидальными и криминальными действиями по сравнению с пациентами II группы. При в целом сопоставимых данных о психопатологических механизмах совершения общественно опасного деяния, ведущем синдроме, различия в группах наблюдались по параметрам длительности заболевания и тяжести клинической симптоматики по шкале PANSS, за счёт выраженности общих психопатологических симптомов и отрицательных значений композитного индекса. Выявлены достоверно значимые прямые и обратные корреляционные связи между тяжестью криминальной агрессии и рядом характеристик суицидальных действий - возрастом первого акта аутоагрессии $(0,56)$, непсихотическими психопатологическими расстройствами $(0,81)$, аддиктивными формами поведения $(0,62)$, количеством ранее совершённых суицидальных попыток $(0,77)$, истинным вариантом суицидальных действий $(-0,68)$, временным интервалом (суицид-криминал) $(-0,71)$. Заключение: Полученные результаты показывают, что между тяжестью общественно опасных действий, совершаемых пациентами с расстройствами щизофренического спектра, и отдельными проявлениями аутоагрессивного поведения существует тесная взаимосвязь, при этом последние могут выступать в качестве предикторов социальной опасности таких больных.

Ключевые слова: шизофрения, шизотипическое расстройство, суицидальное поведение, гетероагрессия, общественно опасные действия

Прогнозирование социальной опасности больных шизофренией остаётся одной из актуальных проблем судебной психиатрии, поскольку играет важную роль для разработки мер как по её первичной, так и вторичной профилактике $[1,2]$. Среди изучаемых предикторов криминальной агрессии лиц с расстройствами шизофренического спектра, в последние годы большое внимание уделяется исследованию различных паттернов поведения таких пациентов, в том числе суицидальной направленности $[3,4,5]$. Интерес к данной проблематике обусловлен, прежде всего, выявляемым высоким риском аутоагрессии у больных шизофренией, совершивших общественно опасные деяния (ООД) $[6,7]$.

В ряде работ показана взаимосвязь суицидальных попыток в анамнезе с тяжестью правонарушений, их направленностью на лиц из ближнего окружения [8], постгомицидными аутоагрессивными действиями [9]. Большинство исследователей при изучении агрессивных действий пациентов с расстройствами шизофренического спектра опираются на многофакторную модель формирования социально опасного поведения, включающую триаду «синдром - личность - ситуация» [10]. При этом в последние годы появились исследования, в
Prediction of the social danger of patients with schizophrenia remains one of the urgent problems of forensic psychiatry, since it plays an important role in the development of measures for both primary and secondary prevention $[1,2]$. Among the studied predictors of criminal aggression of persons with schizophrenic spectrum disorders much attention has been recently paid to the study of various patterns of behavior of such patients, including suicidal orientation $[3,4,5]$. Interest in this issue is primarily due to the identified high risk of auto-aggression in patients with schizophrenia who have committed socially dangerous acts (SDA) $[6,7]$.

A number of works have shown the relationship between a history of suicidal attempts, the severity of offenses, often directed at people from the inner circle [8], and posthomicide autoaggressive actions [9]. Most researchers when studying the aggressive actions of patients with schizophrenic spectrum disorders rely on a multi-factor model of the formation of socially dangerous behavior, including the triad "syndrome - personality - situation" [10]. Moreover, recent studies have appeared 
которых предпринимаются попытки применить данную модель для создания клинической типологии механизмов развития суицидального поведения [11]. Однако вопросы дифференциации причин и клиникопсихологических механизмов сосуществующей у одного пациента ауто- и гетероагрессии, отдельные аспекты взаимосвязи разнонаправленных агрессивных действий, а также прогностическая значимость данных явлений для оценки риска повторности криминального поведения остаются малоизученными. Представляется, что появление новых данных позволит расширить спектр современных взглядов на агрессию больных шизофренией в целом, уточнить подходы к предикции агрессивных ООД, судебно-психиатрической оценке данных состояний, предупреждению рисков внутрибольничной агрессии при осуществлении принудительных мер медицинского характера.

Целью исследования являлось определение связи между суицидальным поведением в анамнезе и особенностями криминальной агрессии у больных шизофренией.

Материалы и методы.

Обследовано 276 пациентов (мужчин) с шизофренией, совершивших ООД, проходивших судебнопсихиатрическую экспертизу в ФГБУ «Национальный медицинский исследовательский центр психиатрии и наркологии им. В.П. Сербского» Минздрава России, в период с 2014 по 2018 гг. В выборку включались пациенты с верифицированным диагнозом шизофрении (F20 по МКБ-10) и шизотипическим расстройством (F21), у которых в анамнезе отмечались суицидальные попытки. В исследование не включались лица подросткового возраста, пациенты с шизофреноподобными расстройствами различной нозологической принадлежности, а также случаи начала заболевания после совершённого ООД.

Возраст пациентов был от 18 и до 60 лет (в сред-

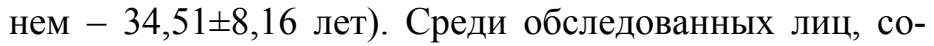
стояние которых соответствовало рубрике F20 (n=92), преобладали $(81,5 \%)$ пациенты с параноидной формой шизофрении, в $10,9 \%$ случаев диагностирована недифференцированная форма (F20.3), в 4,3\% - простая (F20.6) и в $3,3 \%$ - остаточная шизофрения (F20.5). Шизотипические расстройства (F21) наблюдались у 184 пациентов и были представлены в большинстве случаев $(85,9 \%)$ псевдопсихопатической шизофренией (F21.4), в 9,2\% - псевдоневротической (F21.3), в 3,3\% бедной симптомами (F21.5) и в $1,6 \%$ - шизотипическим личностным расстройством (F21.8). Длительность заболевания составила от 1 года до 39 лет (в среднем $13,84 \pm 9,26$ лет).

Основными методами исследования были клиникопсихопатологический, психометрический, статистиче- that attempt to apply this model to create a clinical typology of the mechanisms of development of suicidal behavior [11]. However, we still poorly understand the issues of differentiating the causes and clinical and psychological mechanisms of auto- and heteroaggression coexisting in one patient, certain aspects of the relationship of multidirectional aggressive actions, as well as the prognostic significance of these phenomena to assess the risk of repeated criminal behavior. It seems that the emergence of new data will expand the range of modern views on the aggression of patients with schizophrenia in general, clarify approaches to predicting aggressive SDA, forensic psychiatric assessment of these conditions, and the prevention of risks of nosocomial aggression in the implementation of coercive medical measures.

The aim of the study was to determine the relationship between a history of suicidal behavior and the characteristics of criminal aggression in patients with schizophrenia.

Materials and methods.

We examined 276 patients (men) with schizophrenia who performed SDA and underwent a forensic psychiatric examination at the Ministry of Health of Russia FSBI National Medical Research Center for Psychiatry and Narcology after V.P. Serbsky, from 2014 to 2018 The sample included patients with a verified diagnosis of schizophrenia (F20 according to ICD-10) and schizotypal disorder (F21), who had history of suicidal attempts. The study did not include adolescents, patients with schizophrenia-like disorders of various nosological affiliations, as well as cases of the onset of the disease after a complete SDA.

The age of the patients varied from 18 to 60 years (average - 34.51 \pm 8.16 years). Among the examined individuals whose condition corresponded with F20 ( $\mathrm{n}=92)$, patients with paranoid form of schizophrenia prevailed $(81.5 \%)$, undifferentiated form (F20.3) was diagnosed in $10.9 \%$ of cases, simple type was discovered in $4.3 \%$ (F20.6) and 3.3\% reported residual schizophrenia (F20.5). Schizotypic disorders (F21) were observed in 184 patients and were represented in most cases (85.9\%) by pseudo-psychopathic schizophrenia (F21.4), by pseudo-neurotic in 9.2\% (F21.3), poor in symptoms in 3.3\% (F21.5) and schizotypal personality disorder in $1.6 \%$ (F21.8). The duration of the disease ranged from 1 year to 39 years (average $13.84 \pm 9.26$ years).

The main research methods were clinicalpsychopathological, psychometric, statistical. The data obtained during the survey were 
ский. Полученные в ходе обследования данные вносились в специально разработанную под задачи исследования базисную карту, являющуюся основой для последующей статистической обработки материала. Оценка клинических симптомов шизофрении проводилась с помощью Шкалы позитивных и негативных синдромов (PANSS). Использовалась современная версия шкалы PANSS [12], состоящая из 33 признаков, оцениваемых по 7 градациям выраженности. Вычислялась тяжесть продуктивной симптоматики (7 признаков), негативных расстройств (7 признаков), выраженность других психических нарушений (16 признаков), композитный индекс (разница суммы баллов шкалы позитивных синдромов и шкалы негативных синдромов). Математическую обработку данных проводили с помощью программ SPSS-Statistics и Statistica 12. Качественные признаки описывали с помощью абсолютных и относительных (\%) показателей, количественные - с расчётом средней величины и стандартного отклонения $(\mathrm{M} \pm \mathrm{SD})$. При проведении корреляционного анализа применялась r-корреляция Спирмена. За критический уровень значимости Р при проверке гипотез был принят 0,05 .

Результаты и обсуждение.

Среди всех обследованных пациентов с шизофренией и шизотипическим расстройством правонарушения, сопровождавшиеся выраженными гетероагрессивными действиями (убийства, нанесение тяжких телесных повреждений, угроза убийством, изнасилования), совершили 45,3\% (n=125) человек - I группа, криминальные деяния без агрессивных тенденций отмечались у $54,7 \%$ (n=151) пациентов - II группа. Такое соотношение отличается от данных литературы [13], свидетельствующих о том, что доля тяжких ООД, совершаемых больными с расстройствами шизофренического спектра, составляет около трети от общего числа. Полученные результаты позволяют предположить, что риск гетероагрессивных противоправных деяний у пациентов с шизофренией, в анамнезе которых отмечались суицидальные тенденции, выше. Однако данная интерпретация нуждается в подтверждении сравнительными исследованиями, особенно с учётом специфики контингента лиц, направляемых на судебнопсихиатрическую экспертизу в Центр Сербского.

Важно отметить, что в I группе пациенты с диагнозом «Шизофрения» составили 44,8\% (n=56) случаев, тогда как во II - лишь 23,8\% (n=36), различия статистически достоверны ( $\mathrm{p}=0,00124)$. Соответственно, «Шизотипическое расстройство» было диагностировано в $55,2 \%(\mathrm{n}=69)$ наблюдений среди обследованных I группы и 76,2\% (n=115) - II. С одной стороны, полученное распределение согласуется с имеющимися в литературе данными о более высоком риске соверше- entered into a base map specially developed for the research tasks, which is the basis for subsequent statistical processing of the material. The clinical symptoms of schizophrenia were assessed using the Positive and Negative Syndrome Scale (PANSS). We used the modern version of the PANSS scale [12], consisting of 33 characters, evaluated by 7 gradations of severity. The severity of productive symptoms (7 signs), negative disorders ( 7 signs), the severity of other mental disorders (16 signs), and the composite index (difference in the sum of the points of the scale of positive syndromes and the scale of negative syndromes) were calculated. Mathematical data processing was carried out using SPSSStatistics and Statistica 12 programs. Qualitative characteristics were described using absolute and relative $(\%)$ indicators, quantitative characteristics were calculated using the mean value and standard deviation $(\mathrm{M} \pm \mathrm{SD})$. When conducting a correlation analysis, Spearman $\mathrm{r}$ correlation was used. 0.05 was taken as a critical level of significance $\mathrm{P}$ when testing hypotheses.

Results and discussion.

Among all examined patients with schizophrenia and schizotypal disorder, offenses accompanied by pronounced heteroaggressive actions (homicide, serious bodily harm, threat of murder, rape) were committed by $45.3 \%$ $(n=125)$ people of group I, criminal acts with no aggressive tendencies were observed in $54.7 \%(n=151)$ patients of group II. This ratio differs from the literature data [13], which indicate that the proportion of severe SDA committed by patients with schizophrenic spectrum disorders is about one third of the total. The obtained results suggest that the risk is higher for heteroaggressive illegal acts in schizophrenic patients with the history of suicidal tendencies. However, this interpretation needs to be confirmed by comparative studies, especially taking into account the specifics of the contingent of persons sent to the Serbsky Center for forensic psychiatric examination.

It is important to note that in group I patients with a diagnosis of schizophrenia accounted for $44.8 \%(n=56)$ of cases, while in group II only $23.8 \%(\mathrm{n}=36)$, the differences are statistically significant $(\mathrm{p}=0.00124)$ Accordingly, "Schizotypic disorder" was diagnosed in $55.2 \% \quad(n=69)$ of the observations among the examined group I and $76.2 \%$ $(n=115)$ in the group II. On the one hand, the distribution obtained is consistent with the literature data on a higher risk of serious SDA in patients with productive symptoms, and on the other hand, it suggests that history of sui- 
ния тяжких ООД пациентами с продуктивной симптоматикой, с другой, позволяет предполагать, что наличие суицидальных попыток в анамнезе имеет бо̀льшую значимость для прогнозирования гетероагрессивного криминального поведения при шизофрении, чем при шизотипическом расстройстве.

Средний возраст пациентов I группы на момент исследования был равен $31,6 \pm 5,11$, II группы - 37,2 $\pm 9,47$ годам, различия достигали уровня статистически значимых ( $\mathrm{p}=0,00346)$. Длительность заболевания достоверно менее продолжительной была у лиц, совершивших тяжкие ООД, и составляла в среднем $10,7 \pm 4,24$ лет в I группе и $16,4 \pm 6,11$ - во II ( $\mathrm{p}=0,02728)$.

Возраст впервые совершённых суицидальных попыток у обследованных пациентов в обеих группах приходился преимущественно на период 14-18 лет, однако в I группе доля таких наблюдений (55,2\%; $\mathrm{n}=69)$ была достоверно ниже, чем во II $(81,5 \%$; $\mathrm{n}=123$; $\mathrm{p}=0,01516)$. Статистически значимые различия по данному показателю обнаруживались также для возраста 26-30 лет $(30,4 \% ; n=38$ в I группе и 4,6\%; n=7 - во II; $\mathrm{p}=0,00672)$, тогда как в другие периоды жизни их выявлено не было. Следует отметить, что более ранний возраст первых суицидальных действий был характерен для пациентов с псевдопсихопатической шизофренией, а более старший - для больных параноидной шизофренией.

Средняя продолжительность шизофренического процесса до совершения пациентами первых аутоагрессивных попыток была достоверно выше в I группе $5,9 \pm 3,12$ лет, чем во II $-2,8 \pm 1,56$ лет ( $=0,00241)$. До манифестации заболевания признаки суицидального поведения статистически реже $(\mathrm{p}=0,00822)$ обнаруживали пациенты I группы (12,8\%; n=16), по сравнению со II $(21,2 \% ; \mathrm{n}=32)$. На первые пять лет течения шизофрении приходилась основная часть, совершённых больными аутоагрессивных действий, в обеих группах (72,8\%; $\mathrm{n}=91$ и $68,2 \% ; \mathrm{n}=103$, соответственно), значимых различий не отмечалось $(\mathrm{p}=0,72)$. На более отдалённых этапах заболевания первые акты аутоагрессии встречались реже и достоверно в группах не различались (табл. 1). cidal attempts is more important for predicting heteroaggressive criminal behavior in schizophrenia than with schizotypal disorder.

The average age of patients of group I at the time of the study was $31.6 \pm 5.11$, group II $-37.2 \pm 9.47$ years, the differences reached the level of statistically significant $(\mathrm{p}=0.00346)$. The duration of the disease was significantly shorter for those who had severe SDA, and averaged $10.7 \pm 4.24$ years in group I and $16.4 \pm 6.11$ in group II $(\mathrm{p}=0.02728)$.

The age of the first suicide attempt in the examined patients in both groups fell mainly between 14-18, however, in the first group the proportion of such observations (55.2\%; $\mathrm{n}=69$ ) was significantly lower than in the second $(81.5 \% ; \mathrm{n}=123 ; \mathrm{p}=0.01516)$. Statistically significant differences in this indicator were also found for the age of $26-30$ years $(30.4 \%$; $\mathrm{n}=38$ in group I and $4.6 \% ; \mathrm{n}=7$ in group II; $\mathrm{p}=0.00672$ ), while in other life periods they were not identified. It should be noted that an earlier age of the first suicidal action was characteristic for patients with pseudopsychopathic schizophrenia, and an older one for patients with paranoid schizophrenia.

The average duration of the schizophrenic process until patients committed their first auto-aggressive attempt was significantly higher in group I $-5.9 \pm 3.12$ years than in group II $-2.8 \pm 1.56$ years $(\mathrm{p}=0.00241)$. Before the onset of the disease, signs of suicidal behavior were statistically less likely ( $\mathrm{p}=0.00822$ ) to be found in patients of group I $(12.8 \%, \mathrm{n}=16)$, compared with group II $(21.2 \% ; n=32)$. In the first five years of the course of schizophrenia, the main part was made by patients with autoaggressive actions in both groups $(72.8 \% ; \mathrm{n}=91$ and $68.2 \%$; $\mathrm{n}=103$, respectively), no significant differences were noted $(\mathrm{p}=0,72)$. At more distant stages of the disease, the first acts of autoaggression were less common and did not differ significantly between groups (Table 1).

Таблиц̨а 1 / Table 1

Частота впервые совершённых суицидальных действий в исследуемых группах в зависимости от этапа шизофренического процесса / The frequency of the first committed suicidal actions in the studied groups, depending on the stage of the schizophrenic process

\begin{tabular}{|c|c|c|c|c|c|}
\hline \multirow{3}{*}{$\begin{array}{c}\text { Этап шизофренического } \\
\text { процесса } \\
\text { Schizophrenic process stage }\end{array}$} & \multicolumn{4}{|c|}{$\begin{array}{c}\text { Частота суицидальных действий } \\
\text { Suicide actions frequency }\end{array}$} & \multirow{3}{*}{$\mathrm{P}$} \\
\hline & \multicolumn{2}{|c|}{ I группа / I group (n=125) } & \multicolumn{2}{|c|}{ II группа / II group (n=151) } & \\
\hline & $\mathrm{n}$ & $\%$ & $\mathrm{n}$ & $\%$ & \\
\hline Доманифестный / Pre-manifest & 16 & 12,8 & 32 & 21,2 & 0,0082 \\
\hline $\begin{array}{l}\text { Первые } 5 \text { лет заболевания } \\
\text { First } 5 \text { years of the disease }\end{array}$ & 91 & 72,8 & 103 & 68,2 & 0,7200 \\
\hline $\begin{array}{l}\text { Более } 5 \text { лет заболевания } \\
\text { Over } 5 \text { years of the disease }\end{array}$ & 18 & 14,4 & 16 & 10,6 & 0,0936 \\
\hline
\end{tabular}


Количество совершённых пациентами суищидальHblx попыток в период, предшествовавший правонарушению, было существенно выше в I группе и составляло в среднем $3,7 \pm 1,85$ случаев, тогда как во II группе - лишь 2,1 $\pm 0,76(\mathrm{p}=0,02741)$.

Изучение актуального психического состояния обследованных больных на момент совершения акта аутоагрессии показало, что у пациентов обеих групп преобладающими выступали непсихотические состояния, представленные преимущественно расстройствами психопатоподобного, в ряде случаев, неврозоподобного спектра $(71,2 \%$; $=89$ в I группе и $78,1 \%$; $=118$ - во II), существенно реже - психотические $(28,8 \% ; n=36$ и $21,9 \% ; n=33$, соответственно). При этом аддиктивные формы поведения (в большинстве случаев употребление алкогольных напитков) достоверно чаще $(\mathrm{p}=0,03082)$ сопутствовали суицидальным действиям пациентов I группы (47,2\%; n=59), чем II $(35,8 \%$; $=54)$.

Истинные суицидальные попытки статистически значимо преобладали у больных I группы (29,6\%; n=37 против $11,9 \% ; \mathrm{n}=18 ; \mathrm{p}=0,14261)$, в то время как демонстративные акты аутоагрессии встречались у них достоверно реже по сравнению со II группой $(\mathrm{p}=0,03188)$. Психопатологическая мотивация суицидальных действий наблюдалась в обеих группах с сопоставимой частой $(25,6 \% ; n=32$ в I группе и $29,8 \% ; n=45$ - во II; $\mathrm{p}=0,254)$.

Проведённый анализ психического состояния обследованных пациентов на период совершения противоправных действий показал, что в обеих группах преобладающими выступали негативно-личностные психопатологические механизмы ООД $(76,8 \% ; n=96$ в I группе и $80,1 \% ; n=121$ - во II; p=0,69), ведущими в клинической картине чаще были психопатоподобные расстройства $(67,2 \% ; n=84$ и $74,2 \% ; n=112$ соответстставляла $22,4 \%(\mathrm{n}=28)$ в I группе и $19,2 \%(\mathrm{n}=29)$ - во II $(p=0,322)$. венно; $\mathrm{p}=0,182)$, доля психотических синдромов со-

The number of suicide attempts committed by the patients in the period preceding the offense was significantly higher in group I and averaged $3.7 \pm 1.85$ cases, while in group II it was only $2.1 \pm 0.76(\mathrm{p}=0.02741)$

A study of the actual mental state of the examined patients at the time of the act of auto-aggression showed that for the patients of both groups non-psychotic conditions were predominant, represented mainly by disorders of a psychopathic, in some cases, neurosis-like spectrum $(71.2 \% ; \mathrm{n}=89$ in group I and $78.1 \%$; $\mathrm{n}=118$ - in II), psychotic conditions were reported much less often $(28.8 \% ; \mathrm{n}=36$ and 21.9\%; $n=33$, respectively). Moreover, addictive behaviors (in most cases, the use of alcoholic beverages) were significantly more often $(\mathrm{p}=0.03082)$ accompanied by suicidal actions of patients of group I $(47.2 \% ; n=59)$ than group II $(35.8 \% ; \mathrm{n}=54)$.

True suicide attempts were statistically significantly predominant in patients of group I ( $29.6 \% ; n=37$ versus $11.9 \% ; n=8 ; p=0.14261$ ), while demonstrative acts of auto-aggression were significantly less common for them in comparison with group II ( $\mathrm{p}=0.03188$ ). Psychopathological motivation for suicidal actions was observed in both groups with comparable frequency $(25.6 \% ; \mathrm{n}=32$ in group I and $29.8 \%$; $\mathrm{n}=45$ in group II; $\mathrm{p}=0.254$ ).

The analysis of the mental state of the examined patients during the period of illegal actions showed that negative and personal psychopathological mechanisms of SDA were prevailing in both groups $(76.8 \% ; \mathrm{n}=96$ in group I and $80.1 \%$; $n=121$ - in II; $\mathrm{p}=0.69$ ), psychopathic disorders were leading in the clinical picture more often $(67.2 \% ; \mathrm{n}=84$ and $74.2 \%$; $\mathrm{n}=112$, respectively; $\mathrm{p}=0.182$ ), the proportion of psychotic syndromes was $22,4 \%(n=28)$ in group I and $19.2 \% \quad(\mathrm{n}=29)$ in group II $(\mathrm{p}=0.322)$.

Таблица 2 / Table 2

Выраженность психопатологической симптоматики и композитный индекс по шкале PANSS в исследуемых группах / The severity of psychopathological symptoms and the PANSS scale composite index in the studied groups

\begin{tabular}{l|c|c|c}
\hline \multicolumn{1}{c|}{ Шкала PANSS / PANSS scale } & I группа / I group (n=125) & II группа / II group (n=151) & P \\
\hline $\begin{array}{l}\text { Позитивные симптомы } \\
\text { Positive symptoms }\end{array}$ & $24,4 \pm 3,53$ & $23,1 \pm 4,12$ & 0,0678 \\
\hline $\begin{array}{l}\text { Негативные симптомы } \\
\text { Negative symptoms }\end{array}$ & $26,1 \pm 5,31$ & $25,6 \pm 4,92$ & 0,2437 \\
\hline $\begin{array}{l}\text { Общие психопатологические симптомы } \\
\text { General psусhораthological symptoms }\end{array}$ & $65,5 \pm 11,22$ & $47,3 \pm 9,95$ & 0,0286 \\
\hline $\begin{array}{l}\text { Общий балл } \\
\text { Тотаl }\end{array}$ & $112,7 \pm 14,28$ & $107,3 \pm 15,31$ & 0,0581 \\
\hline $\begin{array}{l}\text { Композитный индекс } \\
\text { Сотровін іпдех }\end{array}$ & $-2,2 \pm 1,63$ & $-0,4 \pm 1,13$ & 0,0147 \\
\hline
\end{tabular}


Интервал между суицидальной попыткой и настоящим ООД в исследуемых группах

The interval between the suicide attempt and the real SDA in the study groups

\begin{tabular}{|c|c|c|c|c|c|}
\hline \multirow{2}{*}{$\begin{array}{l}\text { Интервал между суицидом и ООД } \\
\text { The interval between suicide and SDA }\end{array}$} & \multicolumn{2}{|c|}{$\begin{array}{l}\text { I группа }(n=125) \\
\text { I group }(n=125)\end{array}$} & \multicolumn{2}{|c|}{$\begin{array}{l}\text { II группа }(\mathrm{n}=151) \\
\text { I group }(\mathrm{n}=151)\end{array}$} & \multirow[t]{2}{*}{$\mathrm{P}$} \\
\hline & $\mathrm{n}$ & $\%$ & $\mathrm{n}$ & $\%$ & \\
\hline До года / Less than a year & 17 & 13,6 & 9 & 5,9 & 0,0074 \\
\hline От года до 3 лет /1-3 years & 41 & 32,8 & 26 & 17,2 & 0,0426 \\
\hline От 3 до 5 лет /3-5 years & 34 & 27,2 & 46 & 30,5 & 0,7839 \\
\hline От 5 до 10 лет $/ 5$-10 years & 29 & 23,2 & 43 & 28,5 & 0,9215 \\
\hline Более 10 лет / Over 10 years & 4 & 3,2 & 27 & 17,9 & 0,0054 \\
\hline
\end{tabular}

Психометрическая оценка психопатологической симптоматики по шкале PANSS позволила установить, что у пациентов I группы статистически значимо более выражена была общая психопатологическая симптоматика $(65,5 \pm 11,22$ баллов), чем у пациентов II группы $(47,3 \pm 9,95$ баллов); также, как и отрицательные значения композитного индекса (-2,2 $\pm 1,63$ против $-0,4 \pm 1,13)$. Показатели позитивного и негативного симптомокомплексов были сопоставимы в обеих группах и статистически достоверных различий не имели (табл. 2).

Длительность периода между ранее совершёнными аутоагрессивными действиями и настоящим ООД в рассматриваемых группах в среднем составляла $5,12 \pm 4,82$ года в I группе и была существенно ниже, чем во II $-7,64 \pm 6,11$ года ( $\mathrm{p}=0,03844)$. При этом достоверные различия были установлены по наиболее коротким интервалам - до 1 года и от года до 3 лет, а также по максимально продолжительному - более 10 лет (табл. 3).

По результатам проведённого корреляционного анализа показатель тяжести правонарушения, сопряженность его с гетероагрессивными действиями, у больных с расстройствами шизофренического спектра обнаруживали прямые, тесные связи с такими характеристиками суицидального поведения в анамнезе, как возраст первого акта аутоагрессии $\left(\mathrm{R}_{\mathrm{Sp}}=0,56\right.$; $\mathrm{p}=0,04319)$, его ассоциированность с непсихотическими психопатологическими расстройствами $\left(\mathrm{R}_{\mathrm{Sp}}=0,81\right.$; $\mathrm{p}=0,0001)$ и аддиктивными формами поведения $\left(\mathrm{R}_{\mathrm{Sp}}=0,62 ; \mathrm{p}=0,02536\right)$, количеством ранее совершённых суицидальных попыток $\left(\mathrm{R}_{\mathrm{sp}}=0,77 ; \mathrm{p}=0,01552\right)$. Выраженные отрицательные связи были установлены между тяжкими криминальными деликтами и истинным вариантом аутоагрессивных действий $\left(\mathrm{R}_{\mathrm{Sp}}=-0,68\right.$; $\mathrm{p}=0,0229)$, а также временным интервалом, разделяющим исследуемые разнонаправленные поведенческие акты $\left(\mathrm{R}_{\mathrm{Sp}}=-0,71 ; \mathrm{p}=0,02271\right)$. Корреляционные связи характеризовались слабой выраженностью для показателей сопряжённости суицидальных действий с начальными проявлениями заболевания $\left(\mathrm{R}_{\mathrm{Sp}}=0,22\right.$; $\mathrm{p}=0,41)$, наличия / отсутствия психопатологической
The psychometric assessment of psychopathological symptoms according to the PANSS scale allowed us to establish that in patients of group I the overall psychopathological symptoms were statistically significantly more pronounced $(65.5 \pm 11.22$ points) than in patients of group II (47.3 \pm 9.95 points ); as well as negative values of the composite index $(-2.2 \pm 1.63$ versus $-0.4 \pm 1.13)$. The indicators of positive and negative symptom complexes were comparable in both groups and did not have statistically significant differences (Table 2).

The duration of the period between previously committed auto-aggressive actions and the current OOD in the groups under consideration was on average $5.12 \pm 4.82$ years in group I and was significantly lower than in group II $7.64 \pm 6.11$ years $(p=0.03844)$. At the same time, significant differences were established for the shortest intervals - up to 1 year and from one year to 3 years, as well as for the longest - more than 10 years (Table 3 ).

According to the results of the correlation analysis, the indicator of the severity of the offense, its conjugation with heteroaggressive actions, in patients with schizophrenic spectrum disorders revealed direct, close connections with such characteristics of suicidal behavior in history as the age of the first act of auto-aggression ( $\mathrm{RSp}=0.56 ; \mathrm{p}=0.04319)$, its association with nonpsychotic psychopathological disorders $(\mathrm{RSp}=0.81 ; \mathrm{p}=0.0001)$ and addictive behaviors ( $\mathrm{RSp}=0.62 ; \mathrm{p}=0.02536$ ), the amount of previously committed suicide attempts $(\mathrm{RSp}=0.77 ; \mathrm{p}=0.01552)$. Expressed negative connections were established between severe criminal offence and true version of auto-aggressive actions ( $\mathrm{RSp}=-0.68$; $\mathrm{p}=0.0229$ ), as well as the time interval dividing the investigated multidirectional behavioral acts $(\mathrm{RSp}=-0.71 ; \mathrm{p}=0.02271)$. Correlation relationships were characterized by weak severity for the indicators of the conjugation of suicidal actions with the initial manifestations 
мотивации аутоагрессии $\left(\mathrm{R}_{\mathrm{S}}=0,36 ; \mathrm{p}=0,285\right)$.

Заключение.

Полученные в ходе проведённого исследования результаты свидетельствуют, прежде всего, о наличии связи между отдельными характеристиками суицидального поведения пациентов с расстройствами шизофренического спектра и тяжестью общественно опасных деяний, которые сопровождаются агрессивными действиями. Установлено, что при шизофреническом процессе у лиц, совершивших особо опасные правонарушения, выявлялись более высокие показатели первого акта аутоагрессии в возрастном периоде 26-30 лет, на начальных (в первые пять лет) этапах заболевания, наблюдалось преобладание истинных суицидальных попыток при их ассоциированности с употреблением алкогольных напитков, менее продолжительный интервал между суицидальными и криминальными действиями по сравнению с пациентами, совершившими деликты небольшой тяжести.

С учётом данных, полученных в процессе корреляционного анализа, ряд особенностей суицидального поведения больных может рассматриваться в качестве факторов риска тяжких ООД, что представляется важным для дальнейшего совершенствования мер по первичной и вторичной профилактике противоправных действий лиц с психическими расстройствами. of the disease $(\mathrm{RSp}=0.22 ; \mathrm{p}=0.41)$, the presence / absence of psychopathological motivation for autoaggression $(\mathrm{RS}=0.36 ; \mathrm{p}=0.285)$.

Conclusion.

The results obtained in the course of the study indicate, first of all, that there is a connection between the individual characteristics of suicidal behavior of patients with schizophrenic spectrum disorders and the severity of socially dangerous acts that are accompanied by aggressive actions. It was found that during the schizophrenic process, persons who committed especially dangerous offenses revealed higher rates of the first act of auto-aggression at the age of 26-30, at the initial (in the first five years) stages of the disease, true suicidal attempts dominated when associated with the use of alcoholic beverages, a shorter interval between suicidal and criminal acts was observed compared to patients who committed minor offences.

Taking into account the data obtained in the process of correlation analysis, a number of features of suicidal behavior of patients can be considered as risk factors for severe SDA, which seems important for further improvement of measures for the primary and secondary prevention of unlawful actions of people with mental disorders.

\section{Литература / References:}

1. Котов В.П., Мальцева М.М. Клинические аспекты первичной профилактики общественно опасных действий психически больных. Сочиальная и клиническая психиатрия. 2004; 1 (14): 77-80. [Kotov V.P., Malceva M.M. Clinical aspects of primary prevention of socially dangerous actions of mentally ill people. Social and clinical psychiatry. 2004; 1 (14): 77-80.] (In Russ)

2. Monahan J., Steadman H.J., Robbibs P.C. et al. Developing a clinically useful actuarial tool for assessing violence risk. The British Journal of Psychiatry. 2000; 176: 312-319.

3. Nedopil N. Crime and violence among mental patients. American Journal of Psychiatry. 2008; 3 (2): 142-149.

4. Хамитов Р.Р. Сопряженность клинико-демографических показателей с характером деликтов психически больных представляющих особую опасность. Российский психиатрический журнал. 2003; 3: 42-46. [Khamitov R.R. The correlation of clinical and demographic indicators with the nature of torts of mentally ill persons representing a special danger. Russian psychiatric journal. 2003; 3: 42-46.] (In Russ)

5. Усов Г.М. Оценка значимости предикторов криминальной и некриминальной агрессии лиц, страдающих психическим расстройством. Сибирский вестник психиатрии $u$ наркологии. 2005; 3 (37): 21-23. [Usov G.M. Assessment of the significance of predictors of criminal and non-criminal aggression of persons suffering from mental disorder. Siberian journal of psychiatry and narcology. 2005; 3 (37): 21-23.] (In Russ)

6. Жардецкий А.Н. Аутоагрессивное поведение обвиняемых (типология, судебно-психиатрическая оценка, прогноз): Автореф. дис... канд. мед. наук. М., 2003; 25 с. [Zhardecky A.N. Autoaggressive behavior of the accused (typology, forensic psychiatric assessment, prognosis). Moscow, 2003. 25 p.] (In Russ)

7. Винникова И.Н. Вопросы предикции общественно опасных действий больных шизофренией на современном этапе. Российский психиатрический журнал. 2008; 3: 4-9.
[Vinnikova I.N. Issues of predicting socially dangerous actions of patients with schizophrenia at the present stage. Russian psychiatric journal. 2008; 3: 4-9. (In Russ)

8. Осколкова С.Н., Печенкина О.И. К вопросу о суицидальном поведении больных шизофренией, совершивших агрессивные общественно опасные деяния. Российский психиатрический журнал. 2009; 1: 10-15. [Oskolkova S.N., Pechenkina O.I. To the question of suicidal behavior of patients with schizophrenia who committed aggressive socially dangerous acts. Russian psychiatric journal. 2009; 1: 10-15.] (In Russ)

9. Голенков А.В. Распространенность и особенности постгомицидных суицидов на примере одного из регионов России. Психическое здоровье. 2018; 16 (2): 9-13. [Golenkov A.V. Prevalence and peculiarities of post-homicide suicides on the example of one of the regions of Russia. Mental health. 2018; 16 (2): 9-13.] DOI: 10.25557 / 2074-014X.2018.02.9-13 (In Russ)

10. Кондратьев Ф.В. Аспекты проблемы общественной опасности лиц с психическими расстройствами. Российский психиатрический журнал. 2006; 3: 64-68. [Kondrat'ev F.V. Aspects of the problem of public danger of persons with mental disorders. Russian psychiatric journal. 2006; 3: 64-68.] (In Russ)

11. Распопова Н.И. Психопатологические механизмы суицидального поведения у больных с психическими расстройствами. Психическое здоровье. 2011; 11 (66): 49-52. [Raspopova N.I. Psychopathological mechanisms suicidal behavior in patients with mental disorders. Mental health. 2011; 11 (66): 49-52.] (In Russ)

12. Мосолов С.Н. Шкалы психометрической оценки симптоматики шизофрении и концепция позитивных и негативных расстройств. M, 2001. 238 c. [Mosolov S.N. Scales of psychometric assessment of symptoms of schizophrenia and the concept of positive and negative disorders. M, 2001. 238 s.] (In Russ)

13. Котов В.П., Мальцева М.М. Потенциальная общественная опасность психически больных, ее значение и принципы адекватной диагностики. Российский психиатрический журнал. 2006; 2: 10-14. [Kotov V.P., Malceva M.M. Potential 
social danger of mentally ill people, its significance and principles of adequate diagnosis. Russian psychiatric journal. 2006; 2 :

10-14.] (In Russ)

\title{
SUICIDAL BEHAVIOR AS A RISK FACTOR OF SOCIAL DANGER IN PATIENTS WITH SCHIZOPHRENIC SPECTRUM DISORDERS
}

\author{
I.N. Vinnikova, A.S. Dmitriev, B.S. Polozhy, O.I. Pechenkina, D.Yu. Ermolaeva \\ V. Serbsky National Medical Research Centre for Psychiatry and Narcology, Moscow, Russia; irvina1@yandex.ru
}

\section{Abstract:}

The aim of this study was to determine the relationship between a history of suicidal behavior and the characteristics of criminal aggression in patients with schizophrenia. Materials and Methods: 276 patients with schizophrenia and schizotypal disorder who committed socially dangerous acts and underwent a forensic psychiatric examination at the Federal State Budget Scientific Research Center after V.P. Serbsky. All examined patients had a history of suicidal attempts. The study used clinical, psychopathological and psychometric methods. The clinical symptoms of schizophrenia were assessed using the Positive and Negative Syndrome Scale (PANSS). Depending on the severity of the committed illegal act, the subjects were divided into two groups: I - with manifestations of heteroagression and II without it. Mathematical data processing was performed using SPSS-Statistics and Statistica 12 programs. Results: It was found that the characteristics of suicidal behavior of group I patients significantly differed by higher rates of the commission of the first auto-aggression act at the age of 26-30, at the initial stages of the disease, the prevalence of true suicidal attempts, their association with the use of alcoholic beverages, shorter intervals between suicidal and criminal actions compared with II group patients. With generally comparable data on the psychopathological mechanisms of committing a socially dangerous act, the leading syndrome, differences in the groups were observed in terms of the duration of the disease and the severity of clinical symptoms on the PANSS scale, due to the severity of general psychopathological symptoms and negative values of the composite index. Reliably significant direct and inverse correlations were found between the severity of criminal aggression and a number of characteristics of suicidal actions the age of the first act of auto-aggression (0.56), nonpsychotic psychopathological disorders (0.81), addictive behaviors $(0.62)$, the number of previously committed suicidal attempts $(0.77)$, true version of suicidal actions $(-0.68)$, the time interval (criminal suicide) (-0.71). Conclusion: The results obtained show that there is a close relationship between the severity of socially dangerous acts performed by patients with schizophrenic spectrum disorders and individual manifestations of auto-aggressive behavior, while the latter can act as predictors of the social danger of such patients.

Keywords: schizophrenia, schizotypal disorder, suicidal behavior, heteroagression, socially dangerous actions

Вкмад авторов:

И.Н. Винникова: разработка дизайна исследования, анализ полученных данных, написание текста рукописи;

А.С. Дмитриев: получение данных дмя анализа, обзор публикаций по теме статьи, редактирование текста рукописи;

Б.С. Положий: написание и редактирование текста рукописи;

О.И. Печенкина: получение данных дмя анализа;

Д.Ю. Ермолаева: получение данных дмя анализа.

Authors' contributions:

I.N. Vinnikova: developing the research design, analysis of the obtained data, article writing;

A.S. Dmitriev: $\quad$ obtaining data for analysis, reviewing of publications of the article's theme, article editing;

B.S. Polozhy: article writing, article editing;

O.I. Pechenkina: obtaining data for analysis;

D.Yu. Ermolaeva: obtaining data for analysis.

Финансирование: Данное исследование не имело финансовой поддержки.

Financing: The study was performed without external funding.

Конфликт интересов: Авторы заявляют об отсутствии конфмикта интересов.

Conflict of interest: The authors declare no conflict of interest.

Статья поступила / Article received: 02.09.2019. Принята к публикации / Accepted for publication: 22.12.2019.

Для цитирования: Винникова И.Н., Дмитриев А.С., Положий Б.С., Печенкина О.И., Ермолаева Д.Ю. Суицидальное поведение как фактор риска социальной опасности пациентов с расстройствами шизофренического спектра. Суицидология. 2019; 10 (4): 76-84. doi.org/10.32878/suiciderus.19-10-04(37)-76-84

For citation: $\quad$ Vinnikova I.N., Dmitriev A.S., Polozhy B.S., Pechenkina O.I., Ermolaeva D.Yu. Suicidal behavior as a risk factor of social danger in patients with schizophrenic spectrum disorders. Suicidology. 2019; 10 (4): 76-84. (In Russ) doi.org/10.32878/suiciderus.19-10-04(37)-76-84 